\title{
Molecular Characterization of Phytoplasma Associated with Crops, Weeds and Forest Trees in Andhra Pradesh, India
}

\author{
D. Vijay Kumar Naik ${ }^{1}$, B.V. Bhaskara Reddy ${ }^{2 *}$,J. Sailaja Rani ${ }^{3}$, \\ R. Sarada Jayalakshmi Devi ${ }^{1}$ and K.V. Hari Prasad ${ }^{4}$
}

${ }^{1}$ Department of Plant Pathology, S. V. Agricultural College Tirupati, India

${ }^{2}$ Department of Plant Pathology, IFT, Regional Agricultural Research Station, Tirupati, India

${ }^{3}$ Department of Plant Pathology, Agricultural College, Mahanandi, India

${ }^{4}$ Department of Entomology, S.V. Agricultural College, Tirupati, India

*Corresponding author

A B S T R A C T

Key words

Phytoplasma 16S rDNA, Molecular

characterization, Weeds

and crops

Article Info

Accepted:

07 October 2018

Available Online:

10 November 2018
Totally 32 weed hosts and crop plants were collected and the DNA was isolated from 32 weeds and crops showing phytoplasma disease symptoms and subjected to PCR amplification with phytoplasma specific primers R16F2n/R16R2. The result shows that $\mathrm{R} 16 \mathrm{~F} 2 \mathrm{n} / \mathrm{R} 16 \mathrm{R} 2$ primer amplified $1250 \mathrm{bp}$ product in 19 weeds and other crop species. The notable contribution in the present study was identification of six new hosts for phytoplasma for the first time in the Andhra Pradesh. They are Cleome gynendra, Solanum duclamara, Portulaca oleracea, Aerva lanata, Celosia argentea and Pergularia daemia in Andhra Pradesh.

\section{Introduction}

Phytoplasma are wall less prokaryote bounded by a unit membrane and have cytoplasm, ribosome and nucleic acid and filamentous or polymorphic in shape, bodies ranging from $0.15-1.0 \mu \mathrm{m}$ in diameter and $0.5-1.8 \mu \mathrm{m}$ in length. Phytoplasma transmitted from plant to plant by leafhopper and plant hopper (Florence and Cameron, 1978). Phytoplasmas are generally present in phloem sieve tubes and in the salivary glands of insect vectors. While phytoplasmas are multiply in the phloem, little is known about its mechanism.
A common symptom resulting from phytoplasma infection is phyllody, a condition in which a plant produces leaf like structures instead of flowers, Leaf yellowing, one of the common symptoms associated with the presence of these organisms, phytoplasma infected plants may also show virescence, the development of green flowers due to the loss of pigment in the petal cells and many phytoplasma infected plants acquire a bushy or witches' broom appearance due to changes in their normal growth patterns. Different types of crops and weeds act as a collateral or alternate host for phytoplasma species needs 
to be identified because they may provide reservoirs for disease organisms that infect crop species. In this study 32 crop species and weeds were collected from RARS farm, Tirupati and other places in Andhra Pradesh.

\section{Materials and Methods}

Phytoplasma infected weeds and other crop samples were collected from the fields of Regional Agricultural Research Station (RARS), Tirupati and different places of Chittoor and Anantapur district of Andhra Pradesh. The total DNA from phytoplasma infected plant samples and weed samples were extracted from leaves using CTAB method (Murray and Thomson, 1980). The total isolated DNA used as a template in first round PCR for amplification with P1/P7 primers (Deng and Hiruki. 1991; Smart et al., 1996) followed by nested PCR was done using $2 \mu \mathrm{l}$ of diluted standard PCR product with phytoplasma specific primers R16F2n/R16R2 (Gundersen and Lee.1996).

The first round PCR and nested PCR were carried out sequentially in a final volume of 25 $\mu \mathrm{l}$ reactions containing $2.5 \mu \mathrm{l}$ of $10 \mathrm{X}$ PCR buffer, $2.0 \mu \mathrm{l}(25 \mathrm{mM}) \mathrm{MgCl} 2,0.5 \mu \mathrm{l}(10 \mathrm{mM}$ each) dNTPs, $1.0 \mu \mathrm{l}(10 \mu \mathrm{M})$ each primers, 0.2 $\mu \mathrm{l}$ Taq DNA polymerase $(5 \mathrm{u} / \mu \mathrm{l})$, and $2 \mu \mathrm{l}$ template DNA $(50 \mathrm{ng} / \mu \mathrm{l})$. The DNA was amplified by an initial denaturation of $94^{\circ} \mathrm{C}$ for $4 \mathrm{~min}$ followed by 35 cycles of $94^{\circ} \mathrm{C}$ for 30 seconds denaturation, $56^{\circ} \mathrm{C}$ for $1 \mathrm{~min}$ primer annealing $\left(55^{\circ} \mathrm{C}\right.$ for $1 \mathrm{~min}$ for nested PCR), $72^{\circ} \mathrm{C}$ for 2 min primer extension and final extension at $72^{\circ} \mathrm{C}$ for $10 \mathrm{~min}$.

The PCR products were analysed by electrophoresis in $1 \%(\mathrm{w} / \mathrm{v})$ agarose gel. The DNA fragments in the gel were recorded using gel documentation system. The PCR amplified 1250bp DNA from gel slices was extracted using the ultra-clean gel kit as per the manufacturer's protocol.

\section{Results and Discussion}

Crop and non-crop species with phytoplasma species needs to be identified because they may provide reservoirs for disease organisms that infect crop species. In this study 32 crop species and weeds were collected from RARS farm, Tirupati and other places in Andhra Pradesh. The details of crops and weeds collected from different places, their symptoms and place of collection were given in Table 1.

Thirty two weeds and other crop species showing typical phytoplasma disease symptoms (Fig. 1-2) were collected from the fields of Regional Agricultural Research Station (RARS), Tirupati and Anantapur district. The DNA was isolated from 32 weeds and other crops showing phytoplasma symptoms by CTAB method as described earlier. The amount of DNA and purity of DNA (260/280 ratio) was measured in Nanodrop spectrophotometer. The concentration of DNA ranged from 81.17 $\mathrm{ng} / \mu \mathrm{l}$ to $4094 \mathrm{ng} / \mu \mathrm{l}$ and $260 / 280$ ratios ranged between 1.30 to 2.16 . The extracted DNA gave good amplification of 16S rDNA gene in PCR when used at concentration of $100 \mathrm{ng} / \mu \mathrm{l}$.

The isolated DNA from 32 weeds and other crop species was amplified in nested PCR with $\mathrm{P} 1 / \mathrm{P} 7$ and $\mathrm{R} 16 \mathrm{~F} 2 \mathrm{n} / \mathrm{R} 16 \mathrm{R} 2$ primers and obtained 1800 bp and 1250 bp product respectively. About 32 weeds and other crop species belonging to various families were tested by nested PCR using above two primers and results were furnished in Table 2 .

PCR amplification with R16F2n/R16R2 primer resulted $1250 \mathrm{bp}$ product in 19 weeds and other crop species. They are Cleome gynandra, Solanum duclamara, Portulaca oleracea, Pergularia daemia, Aerva lanata, Celosia argentea, Parthenium hysterophorus, Tephrosia purpurea, Solanum melongena, 
Solanum lycopersicum, Sesamum indicum, Cleome viscosa, Croton bonplandianum, Saccharum officinarum, Citrullus lanatus, Capsicum annuum, Borreria hispida, Cassia auriculata, Arachis hypogaea.

Several workers amplified phytoplasmas rDNA sequence in PCR with universal primers using total DNA isolated from phytoplasma infected Portulaca olaracea (Savita et al.,2014), Pergularia daemia (Rangaswamy et al., 2011), Celosia argentea (Samuitiene and Navalinskiene., 2006), Parthenium hysterophorus (Raj et al., 2008), Tephrosia purpurea (Yadav et al., 2014), Solanum melongena (Kumar et al., 2012), Solanum lycopersicum (Singh et al., 2012) Sesamum indicum (Khan et al., 2007), Cleome viscosa (Li et al., 2014), Saccharum officinarum (Guar et al., 2008), Capsicum annuum (Khan et al., 2005) and Arachis hypogaea (Li et al., 2014).

To determine the 16S rRNA group of phytoplasma associated with certain selected weed species, the 1250 bp rDNA gene from Cleome gynendra, Solanum duclamara, Portulaca oleracea, Aerva lanata, Celosia argentea and Pergularia daemia were gel eluted from agarose gel and cloned into $\mathrm{pTZ57R/T} \mathrm{vector} \mathrm{and} \mathrm{transformed} \mathrm{into}$ competent E. coli cells (JM109) as described earlier.

The recombinant clones containing $1250 \mathrm{bp}$ 16S rDNA gene were identified by Colony PCR with R16F2n/R16R2 primers in above 6 weed species (Fig. 3a). The correct size of the insert was further confirmed by restriction digestion with PstI and EcoRI flanking cloning site in the vector. Restriction digestion with PstI and EcoRI gave two products of approximately $530 \mathrm{bp}$ and $750 \mathrm{bp}$ instead of single product of $1250 \mathrm{bp}$ due to internal restriction site in rDNA sequence in above 6 weed species (Fig. 3b). Several workers cloned the rDNA gene of phytoplasmas infecting Celosia argentea (Samuitiene and Navalinskiene, 2006), Portuluca oleracea (Savita et al., 2014) using universal primer R16F2n/R16R2 in nested PCR.

The clones having correct size of $1250 \mathrm{bp}$ were sequenced using M13 primers and data was assembled using BioEdit software. The partial rDNA sequences of 6 weed species and brinjal infected with phytoplasma were aligned with 26 reference phytoplasma species downloaded from GenBank using BioEdit software to confirm the identity of phytoplasma species associated with 6 weed species and brinjal under study. Multiple sequence analysis of rDNA with reference phytoplasma species belonging to various rDNA groups and sub groups was carried out to confirm the identity. The similarity matrix for phytoplasma infecting weed species and brinjal with 26 other reference phytoplasma isolates were generated using BioEdit software.

The partial rDNA sequence analysis of phytoplasma infecting Cleome gynendra, Pergularia daemia, Portuluca oleracea and Parthenium hysterophorus share 99.4\% identity with ' $C a$. P. australasiae' $16 \mathrm{~S}$ rDNA II-D and papaya mosaic phytoplasma (Y10096). Phytoplasmas infecting Solanum duclamara and Celosia argentea share 100\% rDNA sequence identity with ' $\mathrm{Ca}$. P. australasiae' 16S rDNA II-D and papaya mosaic phytoplasma (Y10096).

Phytoplasma associated with Tephrosia purpurea share $98 \%$ rDNA sequence identity with ' $C a$. P. australasiae' $16 \mathrm{~S}$ rDNA II-D and papaya mosaic phytoplasma (Y10096). Aerva lanata infected with phytoplasma share maximum rDNA sequence identity of 95\% with greengram phyllody (AB690305) from Myanmar and $<94 \%$ with several members of $16 \mathrm{~S}$ rDNA II group. 
Fig.1 Crops showing typical phytoplasma disease symptoms
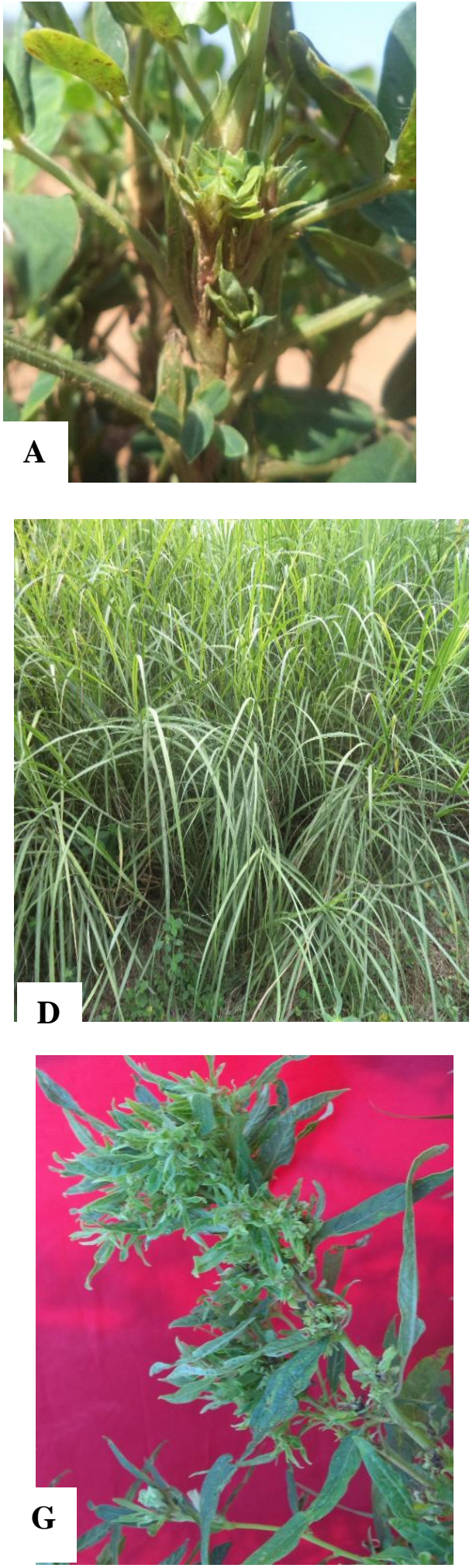
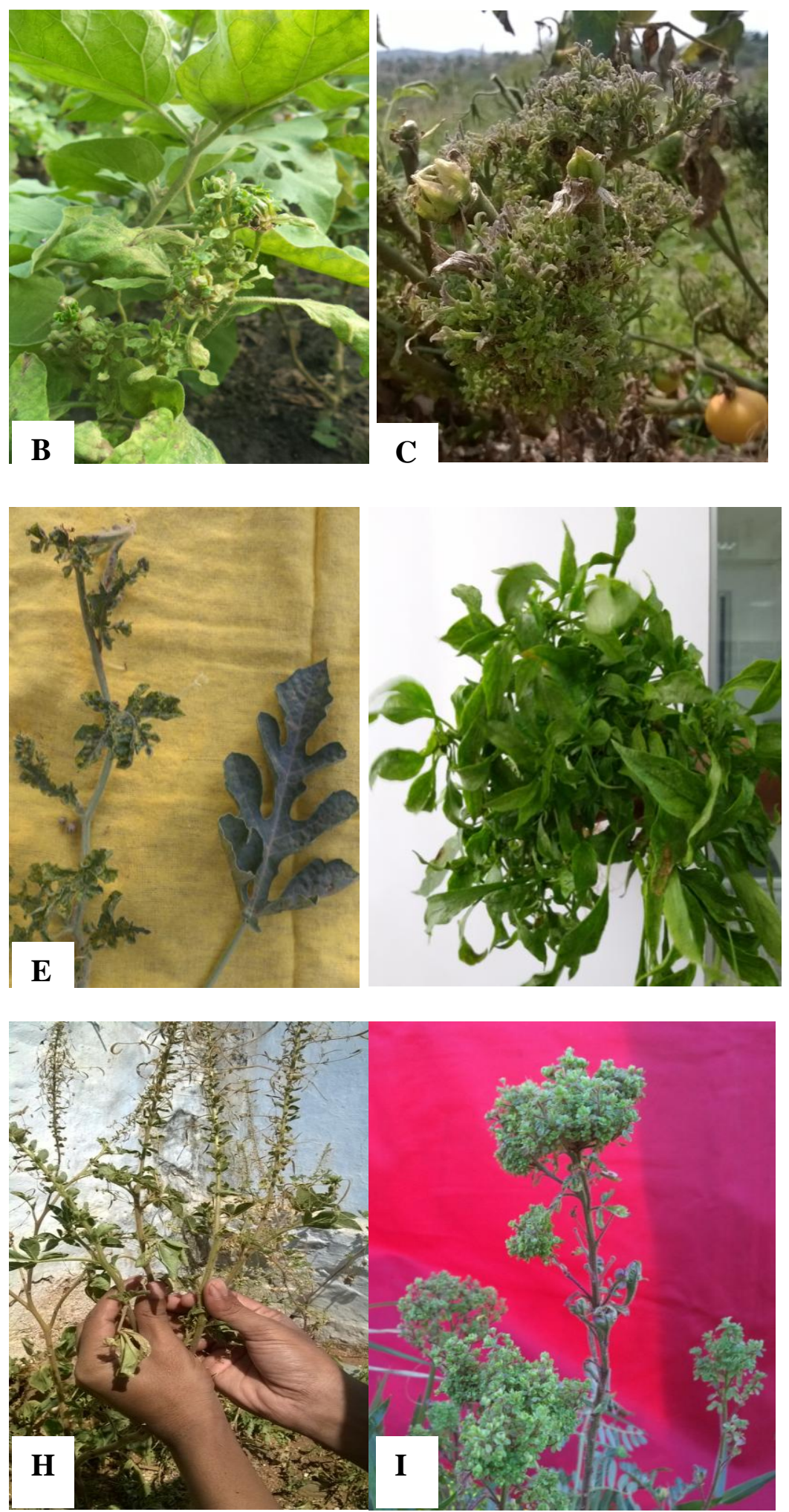

(A) Arachis hypogaea (B) Solanum melongena (C) Solanum lycopersicum (D) Saccharam officinarum (E) Citrullus lanatus (F) Capsicum annuum (G) Sesamum indicum (H) Cleome gynendra (I) Cleome viscose 
Fig.2 Crops showing typical phytoplasma disease symptoms

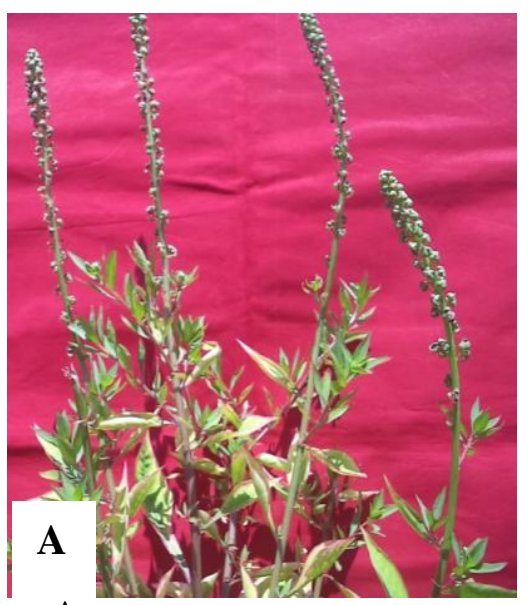

A
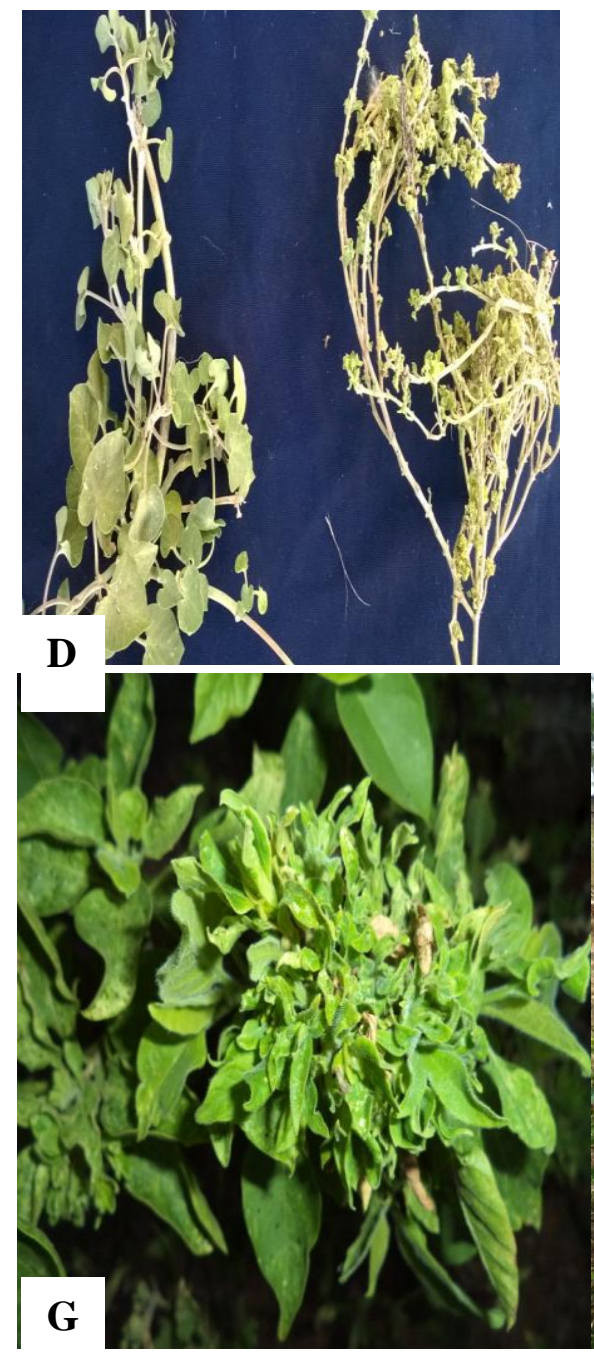

H
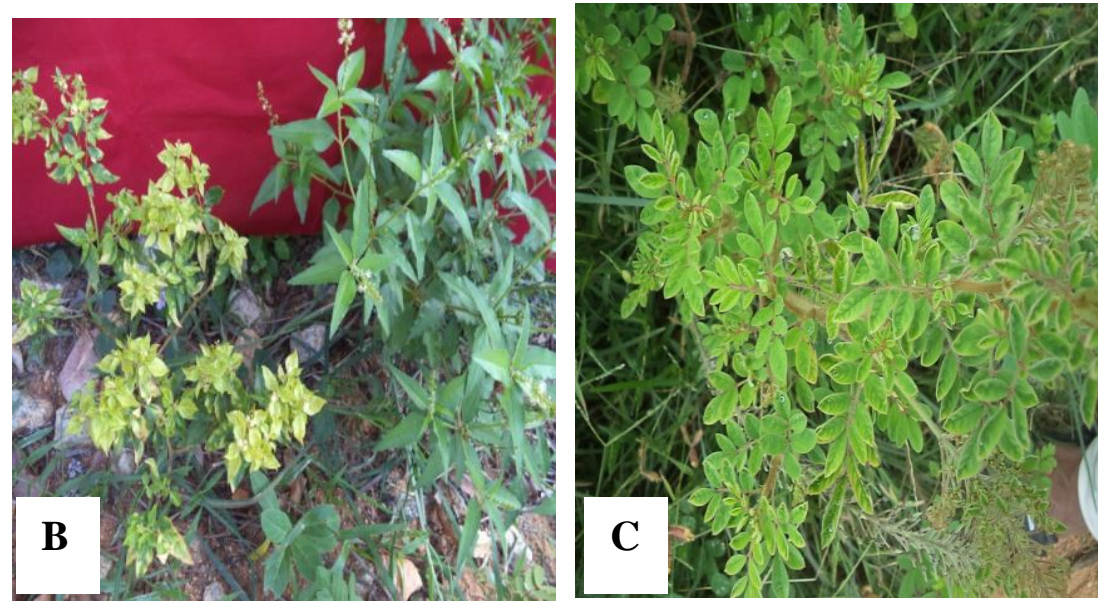

\section{B}
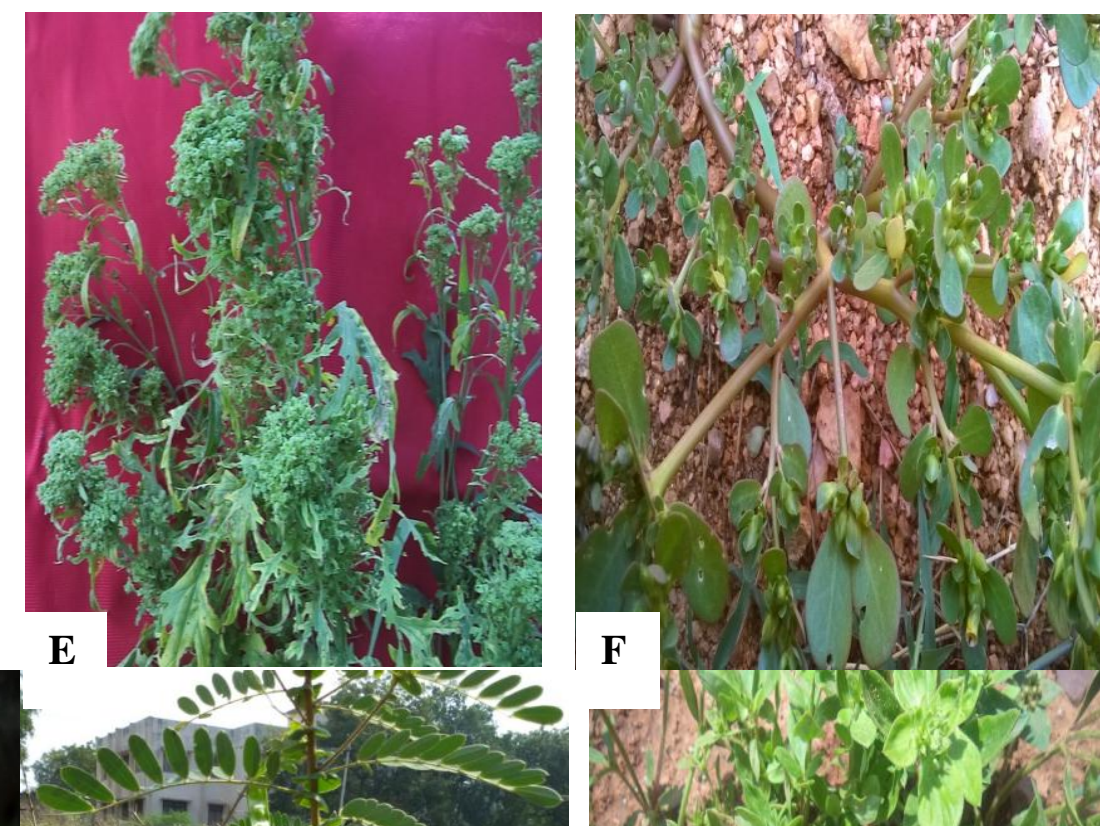

\section{$\mathbf{F}$}

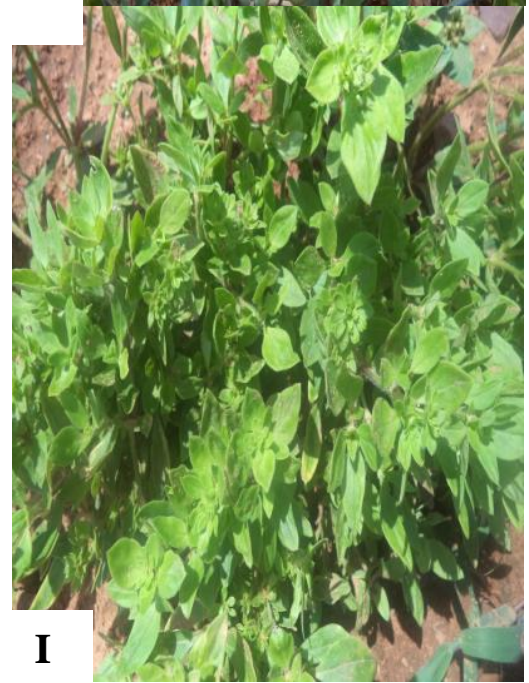

(A) Celosia argentea (B) Croton bonplandianum (C) Tephrosia purpurea (D) Pergularia daemia (E) Parthenium hysterophorus (F) Portulaca oleracea (G) Solanum duclamara (H) Cassia auriculata (I) Borreria hispida 
Fig.3 (a) Confirmation of 16S rDNA clones of phytoplasma by Colony PCR using with R16 F2n/R16R2 primers

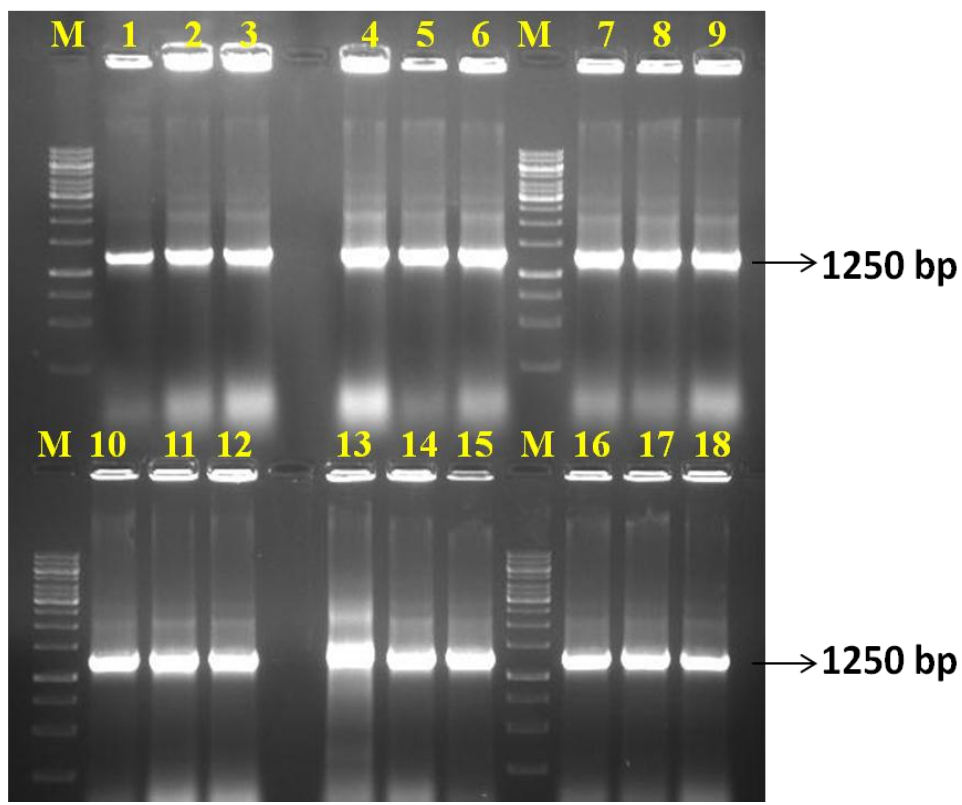

Lanes: M-1 Kb DNA ladder, Lanes: 1, 2, 3-Cleome gynendra, Lanes: 4, 5, 6- Solanum duclamara, Lanes: 7, 8, 9Portulaca olaracea, Lanes: 10, 11, 12- Aerva lanata, Lanes: 13, 14, 15- Celosia argentea, Lanes: 16, 17, 18Pargularia daemia.

Fig.3 (b) Confirmation of 16S rDNA recombinant clones by restriction digestion with Pst1 and Eco $R 1$ in plants

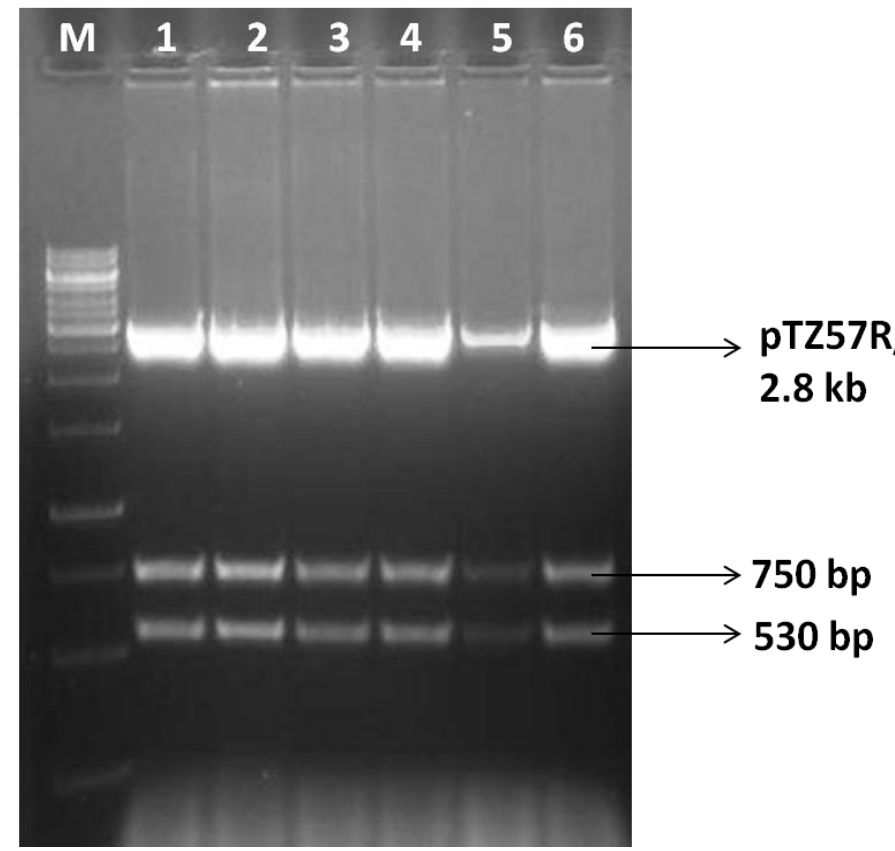

Lanes: M-1 Kb DNA ladder, Lanes: 1-Cleome gynendra, Lanes: 2-Solanum duclamara, Lanes: 3-Portulaca olaracea, Lanes: 4-Aerva lanata, Lanes: 5-Celosia argentea, Lanes: 6-Pargularia daemia. 
Fig.4 Phylogenetic tree sharing the relationship of present isolates under study (marked) with other references isolates from the database

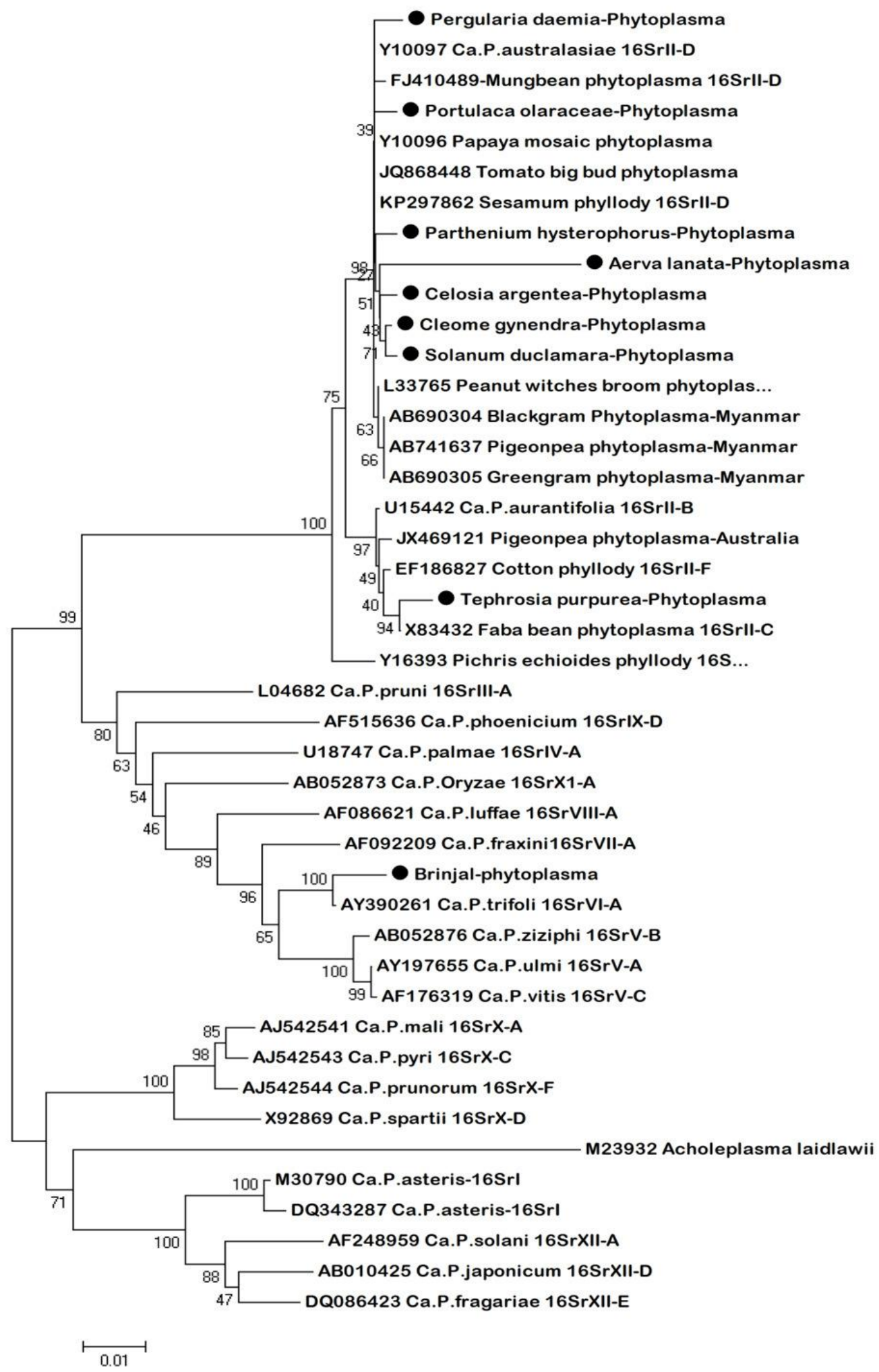


Table.1 List of economically important crop plants and weed hosts collected for detection of phytoplasmas, their families, symptoms and location

\begin{tabular}{|c|c|c|c|c|}
\hline S. No & Name of the crops & Family & Symptoms & Place of collection \\
\hline 01 & Citrullus lanatus & Cucurbitaceae & Little leaves yellowing & Tirupati \\
\hline 02 & Arachis hypogaea & Fabaceae & Phyllody & Tirupati \\
\hline 03 & Capsicum аппиит & Solanaceae & Little leaves & Chittoor \\
\hline 04 & Saccharam officinarum & Poaceae & Narrow leaves, stunted growth & Chandragiri \\
\hline 05 & Solanum melongena & Solanaceae & Little leaves & Chandragiri \\
\hline 06 & Solanum lycopersicum & Solanaceae & Little leaves & Dharmavaram \\
\hline 07 & Sesamum indicum & Pedaliaceae & Phyllody & Tirupati \\
\hline 08 & Cynodon dactylon & Poaceae & Leaf yellowing & Dharmavaram \\
\hline 09 & Parthenium hysterophorus & Asteraceae & Phyllody, Virescence & Dharmavaram \\
\hline 10 & Cleome gynandra & Brassicaseae & Phyllody & Dharmavaram \\
\hline 11 & Solanum duclamara & Solanaceae & Little leaves & Dharmavaram \\
\hline 12 & Aerva lanata & Amaranthaceae & Little leaves & Dharmavaram \\
\hline 13 & Portulaca oleracea & Portulacaceae & Stunted growth, little leaves & Dharmavaram \\
\hline 14 & Pergularia daemia & Asclepiadaceae & Little leaves & Dharmavaram \\
\hline 15 & Celosia argentea & Amaranthaceae & Phyllody, Virescence & Dharmavaram \\
\hline 16 & Cleome viscosa & Brassicaseae & Phyllody & Tirupati \\
\hline 17 & Croton bonplandianum & Euphorbiaceae & Leaf yellowing, little leaves & Tirupati \\
\hline 18 & Borreria hispida & Rubiaceae & Little leaves & Dharmavaram \\
\hline 19 & Acanthospermum hispidum & Asteraceae & Leaf yellowing, little leaves & Tirupati \\
\hline 20 & Acalypha indica & Euphorbiaceae & Leaf yellowing & Tirupati \\
\hline 21 & Tephrosia purpurea & Fabaceae & Leaf yellowing, little leaves & Tirupati \\
\hline 22 & Ziziphus jujube & Rhamnaceae & Leaf yellowing, little leaves & Dharmavaram \\
\hline 23 & Cassia auriculata & Fabaceae & Little leaves & Tirupati \\
\hline 24 & Alternanthera pungens & Amaranthaceae & Leaf yellowing, little leaves & Dharmavaram \\
\hline 25 & Achyranthes aspera & Amaranthaceae & Stunted growth, little leaves & Dharmavaram \\
\hline 26 & Trichodesma indicum & Boraginaceae & Little leaves & Dharmavaram \\
\hline 27 & Commelina benghalensis & Commelinaceae & Little leaves & Tirupati \\
\hline 28 & Eclipta prostrata & Asteraceae & Little leaves & Tirupati \\
\hline 29 & Phyllanthus madaraspatensis & Phyllanthaceae & Little leaves & Dharmavaram \\
\hline 30 & Tribulus terrestris & Zygophyllaceae & Leaf yellowing & Dharmavaram \\
\hline 31 & Amaranthus viridis & Amaranthaceae & Stunted growth, little leaves & Dharmavaram \\
\hline 32 & $\begin{array}{l}\text { Malvastrum } \\
\text { coromandelianum }\end{array}$ & Malvaceae & Leaf yellowing & Dharmavaram \\
\hline
\end{tabular}


Table.2 Detection of phytoplasma in crop plants and weed hosts by nested PCR with primers $\mathrm{P} 1 / \mathrm{P} 7$ and R16F2n/R16R2 primers

\begin{tabular}{|c|c|c|c|}
\hline \multirow[t]{2}{*}{ S. No } & \multirow{2}{*}{$\begin{array}{l}\text { Name of the other crop plants and } \\
\text { weed hosts }\end{array}$} & \multicolumn{2}{|c|}{ primers } \\
\hline & & P1/P7 & R16F2n/R16R2 \\
\hline 01 & Citrullus lanatus & + & + \\
\hline 02 & Arachis hypogaea & + & + \\
\hline 03 & Capsicum аппиит & + & + \\
\hline 04 & Saccharam officinarum & + & + \\
\hline 05 & Solanum melongena & + & + \\
\hline 06 & Solanum lycopersicum & + & + \\
\hline 07 & Sesamum indicum & + & + \\
\hline 08 & Cynodon dactylon & + & + \\
\hline 09 & Parthenium hysterophorus & + & + \\
\hline 10 & Cleome gynendra & + & + \\
\hline 11 & Solanum duclamara & + & + \\
\hline 12 & Aerva lanata & + & + \\
\hline 13 & Portulaca olaracea & + & + \\
\hline 14 & Pergularia daemia & + & + \\
\hline 15 & Celosia argentea & + & + \\
\hline 16 & Cleome viscose & + & + \\
\hline 17 & Croton bonplandianum & + & + \\
\hline 18 & Borreria hispida & + & + \\
\hline 19 & Acanthospermum hispidum & - & - \\
\hline 20 & Acalypha indica & - & - \\
\hline 21 & Tephrosia purpurea & + & + \\
\hline 22 & Ziziphus jujube & - & - \\
\hline 23 & Cassia auriculata & + & + \\
\hline 24 & Alternanthera pungens & - & - \\
\hline 25 & Achyranthes aspera & - & - \\
\hline 26 & Trichodesma indicum & - & - \\
\hline 27 & Commelina benghalensis & - & - \\
\hline 28 & Eclipta prostrata & - & - \\
\hline 29 & Phyllanthus madaraspatensis & - & - \\
\hline 30 & Tribulus terrestris & - & - \\
\hline 31 & Amaranthus viridis & - & - \\
\hline 32 & Malvastrum coromandelianum & - & - \\
\hline
\end{tabular}

The interesting results of present work is that phytoplasma infecting brinjal share maximum identity of $99 \%$ at rDNA sequence level with 'Ca.P.trifolii' 16S rDNA VI-A group, 97\% with 'Ca.P.fraxini' $16 \mathrm{~S}$ rDNA VIII-A and <
95\% with all other reference isolates under analysis.

Phylogenetic and molecular evolutionary analysis were conducted using rDNA 
sequences of phytoplasmas infecting 7 weed species and brinjal with 26 reference phytoplasma isolates by neighbour- joining method using Mega 4.0 software with Acholeplasma laidlawii as out group.

The data was bootstrapped 500 times and percentage values are given at the nodes of the tree (Fig. 4). The phytoplasma infecting Pergularia daemia, Portuluca oleracea, Parthenium hysterophorus, Celosia argentea, Cleome gynendra and Solanum duclamara formed unique cluster with ' $\mathrm{Ca}$. P. australasiae' $16 \mathrm{~S}$ rDNA II-D and papaya mosaic phytoplasma (Y10096), tomato big bud phytoplasma (JQ868448), and sesame phyllody $16 \mathrm{~S}$ rDNA II-D group. From the above results it is clear that phytoplasma infecting above six crops in Andhra Pradesh belongs to 16S rDNA II-D group.

The notable contribution in the present study was identification of six new hosts for phytoplasma for the first time in the India. They are Cleome gynendra, Solanum duclamara, Portulaca olaracea, Aerva lanata, Celosia argentea and Pergularia daemia in Andhra Pradesh.

In the present study association of phytoplasma was observed with Parthenium hysterophorus. Raj et al., (2008) also reported phytoplasma in Parthenium hysterophorus in Bahraich and Gorakhpur districts of Uttar Pradesh, India.

Yadav et al., (2014) reported 'Candidatus Phytoplasma aurantifolia' associated with witches' broom disease of Tephrosia purpurea in India. The present results are in agreement with above report.

Kumar et al., (2012) reported little leaf disease of brinjal caused by 'Candidatus Phytoplasma asteris' in the field of Bihar, India. The present study also confirmed little leaf disease of brinjal in Andhra Pradesh, but causal agent is 'Candidatus Phytoplasma trifolii'. Samuitiene and Navalinskiene. (2006) reported phytoplasma disease on Celosia argentea in
Lithuania.

Amplification by nested PCR and RFLP analysis shows that the plants were infected by the phytoplasma belonging to the $16 \mathrm{~S}$ rI-M subgroup.

The present results also confirmed phytoplasma disease on Celosia argentea but causal agent comes under $16 \mathrm{~S}$ rII group.

The objective of this study was to identify the weed host of phytoplasma infecting pulses in Andhra Pradesh. Because weeds are reservoirs of phytoplasma that infect crop and they play an important part in the emergence of epidemics affecting crops. Weeds may serve as reservoirs of phytoplasmas during the non-cropping season. In this study we have identified several weeds as host for phytoplasmas. Transmission studies from weeds to pulses and vice versa is also required to get information on exact role of them in spreading disease under field conditions.

\section{References}

Deng S, Hiruki C. Amplification of 16S rRNA genes from culturable and non-culturable Mollicutes. Journal of Microbiological Methods. 1991; 14:53-61.

Florence ER, Cameron HR. Three dimensional structure and morphology of mycoplasrna like bodies associated with albino disease of Prunus avium. Phytopathology. 1978; 68:75-80.

Gundersen DE, Lee IM. Ultrasensitive detection of phytoplasmas by nested PCR assays using two universal primer pairs. Phytopathologia Mediterranea. 1996; 35:144-151.

Khan, M.S and Raj, S.K. 2005. First report of molecular detection of an Aster yellows phytoplasma ('Candidatus Phytoplasma' asteris) isolate infecting chilli (Capsicum annuиm) in India. New Disease Reports. 13: 10.

Khan, M.S., Raj, S.K and Snehi, S.K. 2007. First report of Candidatus phytoplasma 
asteris affecting sesame cultivation in India. Journal of Plant Pathology. 89 (2): 301-305.

Kumar, J., Gunapati, S., Singh, S. P., Lalit, A., Sharma, N. C and Tuli, R. 2012. First report of a 'Candidatus Phytoplasma asteris' (16SrI group) associated with little leaf disease of Solanum melongena (brinjal) in India. New Disease Reports. 26: 21.

Li, Y., Piao, C. G., Tian,G. Z., Liu, Z. X., Guo, M. W., Lin, C. L and Wang, X. Z. 2014. Multilocus sequences confirm the close genetic relationship of four phytoplasma of peanut witches' broom group 16SrII-A. Journal of Basic Microbiology. 54(8): 818-827

Murray MG, Thompson WF. Rapid isolation of high molecular weight plant DNA. Nucleic Acids Research. 1980; 8:43214326.

Raj, S. K., Khan, M. S., Snehi, S. K., Mall, S. and Rao, G. P. 2008. First report of Phytoplasma 'Candidatus Phytoplasma asteris' (16SrI) from Parthenium hysterophorus $L$. showing symptoms of virescence and witches'-broom in India. Australasian Plant Disease Notes. 3, 4445

Rangaswamy, K. T., Verma, O. P., Sharma, P., Gour, H. N., Siddiqui, S. R., Shankarappa, K. S., Aswathanarayan and Pramilla, H. A. 2011. 16S rDNA reveals association of phytoplasma with two plant species (Pergularia daemia and Verbesine enceliodes) of medicinal values-a new report. National Academy Science Letters. 34(1\&2): 31-34.

Samuitiene, M and Navalinskiene, M. 2006. Molecular detection and characterization of phytoplasma infecting Celosia argentea L. plants in Lithuania. Agronomy Research. 4: 345-348.

Savita, C., Smriti, M., Upadhaya, P. P and Rao, G. P. 2014. Natural occurrence of 16SrI group phytoplasma on purslane (Portulaca olaracea L.) a medicinal weed species in India. Medicinal Plants International Journal of Phytomedicines and Related Industries. 6(2): 150-153.

Singh, J., Rani, A., Kumar, P., Baranwal, V. K., Saroj, P. L and Sirohi, A. 2012. First report of a 16SrII-D phytoplasma 'Candidatus Phytoplasma australasiae' associated with a tomato disease in India. New Disease Reports. 26: 14.

Smart CD, Schneider B, Blomquist CL, Guerra LJ, Harrison NA, Ahrens $\mathrm{U}$, et al., Phytoplasma Specific PCR primers based on sequences of the 16S-23S rRNA spacer region. Applied and Environmental Microbiology. 1996; 62(8):2988-2993.

Tamura K, Dudley J, Nei M, Kumar S. MEGA 4: Molecular Evolutionary Genetics Analysis (MEGA) software version 4.0. Molecular Biology and Evolution. 2007; 24:1596-1599.

Yadav, A., Bhale, U., Thorat, V and Shouche, Y. 2014. First Report of a New Subgroup $16 \mathrm{Sr}$ II-M 'Candidatus Phytoplasma aurantifolia' associated with Witches' broom disease of Tephrosia purpurea in India. Plant Disease Journal. 98(7): 990.

\section{How to cite this article:}

Vijay Kumar Naik, D., B.V. Bhaskara Reddy, J. Sailaja Rani, R. Sarada Jayalakshmi Devi and Hari Prasad, K.V. 2018. Molecular Characterization of Phytoplasma Associated with Crops, Weeds and Forest Trees in Andhra Pradesh, India. Int.J.Curr.Microbiol.App.Sci. 7(11): 781-791. doi: https://doi.org/10.20546/ijcmas.2018.711.094 